\title{
Cloning of the Rhodobacter sphaeroides hisl gene: unifunctionality of the encoded protein and lack of linkage to other his genes
}

\author{
Esther Oriol, Sebastián Méndez-Álvarez, Jordi Barbé and Isidre Gibert \\ Author for correspondence: Isidre Gibert. Tel: +3435812050 . Fax: +3435812387. \\ e-mail: igibert@cc.uab.es
}

Department of Genetics and Microbiology, Faculty of Sciences, Autonomous University of Barcelona, Bellaterra-08193, Barcelona, Spain

\begin{abstract}
The Rhodobacter sphaeroides 2.4.1 hisl gene, which encodes a phosphoribosylAMP-cyclohydrolase that catalyses the third step in the histidine biosynthetic pathway, has been isolated from a genomic library of this phototrophic bacterium by complementation of an Escherichia coli hisl mutant. Analysis of the nucleotide sequence of the $R$. sphaeroides hisl gene reveals that it encodes a deduced product of 119 aa with a predicted molecular mass of $13.4 \mathrm{kDa}$. In contrast to the situation in $E$. coli, the $R$. sphaeroides hisl gene encodes a unifunctional protein and it is not linked to the hisE gene. The absence of a single histidine operon like that of E. coli was confirmed by PFGE experiments and complementation analysis of a $R$. sphaeroides his/ mutant that was constructed by marker exchange. The location of $h i s l$ in the $R$. sphaeroides genome has been determined to be at map co-ordinate $2275 \pm 20$ of chromosome I.
\end{abstract}

Keywords: bisI gene, Rhodobacter sphaeroides, histidine biosynthesis, chromosome mapping

\section{INTRODUCTION}

The biosynthetic pathway for histidine has been widely studied in different micro-organisms, both prokaryotes and eukaryotes. Although the intermediate products and the enzymes involved seem to be quite similar for diverse organisms, there are important differences among them in terms of gene distribution and regulation mechanisms.

The biosynthesis of histidine is carried out by an unbranched pathway that is more closely linked to the metabolism of pentoses and purines than to any of the other amino acids. This pathway has been analysed in Escherichia coli and Samonella typhimurium both biochemically (Martin et al., 1971) and genetically (Carlomagno et al., 1988). It is known that in these microorganisms the eleven steps of the pathway are catalysed by enzymes encoded by eight structural genes, which are clustered in a single $7.5 \mathrm{~kb}$ operon, organized in the sequence hisGDCBHAF(IE). A primary promoter and two internal promoters (to avoid the polar effect), as well as a rho-independent terminator, have been identified (Winkler, 1987).

Studies in other organisms show that the arrangement of

The EMBL accession number for the nucleotide sequence reported in this paper is $\times 82010$. his genes is very variable. In Lactococcus lactis (Delorme $e t$ al., 1992), the relative order of the genes is the same as in enteric bacteria, but the operon contains additional ORFs of unknown function. In Streptomyces coelicolor (Limauro et al., 1990) several genes are located in a main cluster, while other genes have been found in unlinked loci of the chromosome. A main cluster that does not contain all the genes is also found in Bacillus subtilis (Henner et al., 1986) and Arospirillum brasilense (Fani et al., 1993). In Saccharomyces cerevisiae (Donhaue et al., 1982) and Neurospora crassa (Legerton \& Yanofsky, 1986) the histidine genes are scattered over different chromosomes.

The histidine biosynthetic pathway is extensively used for studies of gene structure, expression and regulation. E. coli and $S$. typhimurium possess an elaborate network to control the rate of histidine biosynthesis, which includes feedback inhibition, metabolic regulation, attenuation and control by supercoiling (Winkler, 1987; O'Byrne et al., 1992). The wide information acquired on his genes allows us to use them as a model system for the study of gene regulation.

To the best of our knowledge there are only two reported sequences of genes related to the biosynthesis of amino acids $(\operatorname{tr} p C$ and $g \ln A B$ ) from photosynthetic organisms (Becker-Rudzik et al., 1992; Zinchenko et al., 1994), and no histidine gene has yet been characterized. The isolation 
of the R. sphaeroides histidine genes would be useful, not only to analyse the metabolic pathway of this amino acid further, but also to provide a model for the study of regulation of biosynthetic genes in a phototrophic bacterium.

As a first step to studying the regulation mechanisms of histidine biosynthesis in $R$. sphaeroides, the bisI gene was isolated by complementation of a characterized mutant of E. coli. This technique takes advantage of the fact that the histidine biosynthesis genes of different species can complement auxotrophic strains of E. coli, even if they are not phylogenetically related (Bazzicalupo et al., 1987).

The E. coli hisIE gene, which is $610 \mathrm{bp}$ in size, is located in the distal part of the histidine operon and encodes a phosphoribosyl-ATP-pyrophosphohydrolase:phosphoribosyl-AMP-cyclohydrolase, which catalyses the second and third steps in the histidine biosynthetic pathway. These include hydrolysis of $N^{\prime}-\left(5^{\prime}\right.$-phosphoribosyl)-ATP to $N^{\prime}$-(5'-phosphoribosyl)-AMP and pyrophosphate ( hisE enzyme activity), followed by a ringopening reaction on the purine (bisI enzyme activity).

In this paper, we report the cloning and sequencing of the bisI gene, as well as its mapping on the chromosome of $R$. sphaeroides and the construction of a hisI mutant. Surprisingly, unlike most micro-organisms studied so far, we have found that the R. sphaeroides bisI gene encodes a unifunctional protein and that it is not linked to the bis $E$ gene.

\section{METHODS}

Bacterial strains and plasmids. These are listed in Table 1.

Media and growth conditions. E. coli and S. typhimurium strains were grown in either complex LB (Miller, 1992) or NB medium (Nutrient Broth no. 2; Oxoid), or minimal AB medium supplemented with $0 \cdot 2 \%(\mathrm{w} / \mathrm{v})$ glucose (Clarke \& Maaløe, 1967 ) at $37^{\circ} \mathrm{C}$ for $16-20 \mathrm{~h}$. Plasmid extracts were made from cultures growing in TB medium (Sambrook et al., 1989).

$R$. sphaeroides strains were grown in complex $\mathrm{Z}$ broth (Pemberton \& Bowen, 1981) or minimal Pfennig medium (Pfennig \& Trupper, 1983) lacking yeast extract and supplemented with $0.2 \%(\mathrm{w} / \mathrm{v})$ sodium succinate. In all cases, growth of R. sphaeroides was performed aerobically in the dark at $30^{\circ} \mathrm{C}$ for $36-48 \mathrm{~h}$.

Media were supplemented when necessary with $25 \mu \mathrm{g}$ histidine $\mathrm{ml}^{-1}, 40 \mu \mathrm{g} \mathrm{X}-\mathrm{Gal} \mathrm{ml^{-1 }}$ or antibiotics at the following concentrations: $17 \mu \mathrm{g}$ tetracycline $\mathrm{ml}^{-1}$ for E. coli and $1.7 \mu \mathrm{g}$ tetracycline $\mathrm{ml}^{-1}$ for R. sphaeroides; $50 \mu \mathrm{g}$ ampicillin $\mathrm{ml}^{-1} ; 34 \mu \mathrm{g}$ chloramphenicol ml ${ }^{-1} ; 75 \mu \mathrm{g}$ rifampicin $\mathrm{ml}^{-1} ; 75 \mu \mathrm{g}$ streptomycin $\mathrm{ml}^{-1}$; $100 \mu \mathrm{g}$ spectinomycin $\mathrm{ml}^{-1}$.

Construction of a $\boldsymbol{R}$. sphaeroides library. R. sphaeroides chromosomal DNA was extracted, partially digested with Sau $3 \mathrm{AI}$ and purified by ultracentrifugation on a sucrose gradient (Ausubel et al., 1989). Fragments of 5-8 kb were ligated to the broad-host-range cloning vector pRK404 (Ditta et al., 1985), previously digested with $B a m H I$. The ligation mix was introduced into $E$. coli DH5 $\alpha$ by electroporation (Dower $e$ t al., 1988), and cells were plated on LB agar supplemented with tetracycline and X-Gal. The library was amplified and maintained at $-70^{\circ} \mathrm{C}$ in $15 \%(\mathrm{w} / \mathrm{v})$ glycerol.
Molecular biology techniques. Plasmid DNA isolation, agarose gel electrophoresis, restriction endonuclease digestions, enzyme treatment and transformation were carried out as described elsewhere (Sambrook et al., 1989). Random primer labelling and Southern blot hybridization were performed following the 'DIG System User's Guide for Filter Hybridization' from Boehringer Mannheim.

Prior to DNA sequencing, a set of exonuclease III-mediated nested deletions of the DNA fragment of interest was obtained, using the Erase-a-Base system (Promega). The DNA sequence was determined for both strands by the dideoxynucleotide chain-termination method (Sanger et al., 1977) on an ALF Sequencer (Pharmacia Biotech) or on a GATC 1500-System DNA sequencer (MWG-Biotech), using M13 primers of pBluescript $\mathrm{SK}(+)$ in both cases.

Nucleic acid and protein sequences were analysed using the University of Wisconsin Genetics Computer Group software package, version 8.0.

Pulsed-field gel electrophoresis. Intact genomic DNAs from R. sphaeroides were prepared in InCert agarose plugs as described by Smith \& Cantor (1987). PFGE was performed in a Pharmacia-LKB apparatus. Gels were made of $1 \%(\mathrm{w} / \mathrm{v})$ agarose (SeaKem LE; FMC) and run at $15^{\circ} \mathrm{C}$ in modified TBE buffer ( $100 \mathrm{mM}$ Tris, $100 \mathrm{mM}$ boric acid, $0 \cdot 2 \mathrm{mM}$ EDTA; final $\mathrm{pH} 8 \cdot 0-8 \cdot 4)$. Electrophoresis conditions were standardized in order to obtain two different resolution windows: $10 \mathrm{~V} \mathrm{~cm}^{-1}$ for $36 \mathrm{~h}$, with a $10-120 \mathrm{~s}$ pulse ramp, resolved fragments from 200 to $1600 \mathrm{~kb} ; 6.6 \mathrm{~V} \mathrm{~cm}^{-1}$ for $24 \mathrm{~h}$, with a $5-35 \mathrm{~s}$ pulse ramp, resolved fragments from 30 to $450 \mathrm{~kb}$. Chromosomes of $S$. cerevisiae YPH80 (Promega) and phage $\lambda$ DNA concatamers (New England Biolabs) were used as size standards.

\section{RESULTS AND DISCUSSION}

\section{Cloning of the $R$. sphaeroides hisl gene}

To isolate the R. sphaeroides bisI gene, a genomic library of this bacterium, constructed as described in Methods, was transferred from E. coli DH5 $\alpha$ to E. coli UA4845 (hisl) by triparental mating, using the plasmid pRK2013 as helper. Transconjugants that grew in the absence of exogenous histidine on plates containing tetracycline and rifampicin were selected. Although E. coli and R. sphaeroides are not closely related, the bisI genes are conserved enough to encode functionally equivalent proteins.

Plasmid pUA509, containing a $4.9 \mathrm{~kb}$ insert, was isolated from one of these transconjugants and further characterized. First, it was introduced by transformation into various $E$. coli his mutants, namely bis $A$, bis $B$, bis $C$, bis $D$, $b i s F$ and $h i s G$, in order to test its ability to complement histidine mutations other than bisl. No complementation was observed in any case. This plasmid was also introduced by electroporation into two different bisI strains of S. typhimurium (SB4281 and I125) in order to test complementation of pUA509 in different genetic backgrounds. In both cases, pUA509 allowed the recovery of the prototrophic phenotype.

An accurate restriction analysis of pUA509 showed that three fragments $(0.9,1.2$ and $1.3 \mathrm{~kb})$ were generated after digestion with Sall. Each of these fragments was subcloned in the SalI site of pBluescript SK, and the constructs were used to transform UA4845. Replica- 
Table 1. Bacterial strains and plasmids used in this study

\begin{tabular}{|c|c|c|}
\hline Strain & Description & Source or reference \\
\hline \multicolumn{3}{|l|}{ Escherichia coli } \\
\hline $\mathrm{DH} 5 \alpha$ & $\begin{array}{l}\operatorname{deo} \mathrm{R} \text { end } A 1 \operatorname{gyr} A 96 \operatorname{rec} A 1 \text { relA1 bsd } 17\left(\mathrm{r}_{\mathrm{K}}^{-} \mathrm{m}_{\mathrm{K}}^{-}\right) \sup \mathrm{E} 44 \text { thi-1 } \Delta(\operatorname{lac} \mathrm{Z} Y A- \\
\operatorname{argF}) \phi 80 \operatorname{lac} \mathrm{Z} \Delta \mathrm{M} 15 \mathrm{~F}^{-} \lambda^{-}\end{array}$ & Hanahan (1983) \\
\hline UTH903 & bisI903 ara-14 galKZ $\lambda^{-}$rpsL145 malT1 $x y l-5$ mtl-1 & Goldschmidt et al. (1970) \\
\hline UA4845 & UTH903 $\mathrm{Rf}^{\mathrm{r}}$ & This study \\
\hline \multicolumn{3}{|c|}{ Salmonella typhimurium } \\
\hline SB4281 & bisla99 & Hartman et al. (1971) \\
\hline I125 & bisI125 & Hartman et al. (1971) \\
\hline E311 & bisE311 & Hartman et al. (1971) \\
\hline UA1701 & bisE311 $\mathrm{Rf}^{\mathrm{r}}$ & This study \\
\hline \multicolumn{3}{|c|}{ Rhodobacter sphaeroides } \\
\hline 2.4 .1 & Wild-type & Kaplan, S. (University of Texas) \\
\hline $\mathrm{UA} 8002$ & Derivative of $2.4 .1, \mathrm{Rf}^{\mathrm{r}}$ & This laboratory \\
\hline UA8123 & Derivative of 2.4.1, $\mathrm{Rf}^{\mathrm{r}} \mathrm{Sp}^{\mathrm{r}} \mathrm{Sm}^{\mathrm{r}} \mathrm{HisI}^{-}$ & This study \\
\hline \multicolumn{3}{|l|}{ Plasmids } \\
\hline pRK404 & $\mathrm{Mob}^{+} \mathrm{Tc}^{\mathrm{r}}$ & Ditta et al. (1985) \\
\hline pRK2013 & $\mathrm{Mob}^{+} \mathrm{Tra}^{+} \mathrm{Km}^{\mathrm{r}}$ & Ditta et al. (1985) \\
\hline pBluescript SK+ & $A p^{r}$ & Stratagene \\
\hline pSUP202 & $A p^{r} \mathrm{Tc}^{r} \mathrm{Cm}^{\mathrm{r}}$ & Simon et al. (1983) \\
\hline $\mathrm{pHP} 45 \Omega S \mathrm{pSm}$ & $A p^{r} S p^{r} S m^{r}$ & Fellay et al. (1987) \\
\hline pUA509 & $\begin{array}{l}\text { pRK } 404 \text { carrying a } 4.9 \mathrm{~kb} \text { R. sphaeroides DNA fragment containing the } \\
\text { bisI gene }\end{array}$ & This study \\
\hline pUA510 & pBluescript SK carrying a $S a l l-S a l l 1.3 \mathrm{~kb}$ DNA fragment from pUA509 & This study \\
\hline pUA534 & $\begin{array}{l}\text { PSUP202 carrying a } B c / I-B g / I 0.5 \mathrm{~kb} \text { fragment from pUA } 510 \text {, disrupted } \\
\text { by a } \Omega \mathrm{Sp} / \mathrm{Sm} \text { interposon }\end{array}$ & This study \\
\hline pUA556 & $\begin{array}{l}\text { pRK } 404 \text { carrying a } 8.8 \mathrm{~kb} \text { R. sphaeroides DNA fragment containing the } \\
\text { bisE gene }\end{array}$ & This study \\
\hline
\end{tabular}

(a)
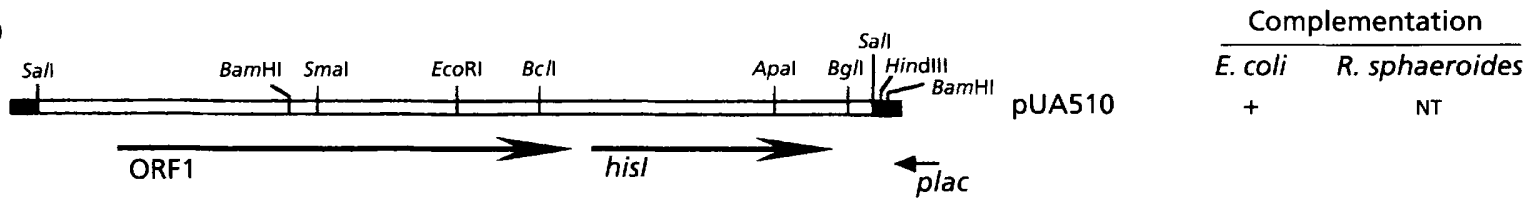

(b)

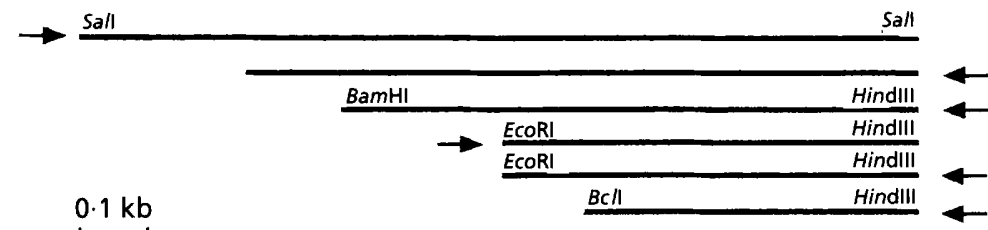

$0.1 \mathrm{~kb}$

$\underline{B C H}$

$\leftarrow$

$\begin{array}{ll}+ & \text { NT } \\ - & \text { NT } \\ - & + \\ + & \text { NT } \\ - & \text { NT } \\ - & +\end{array}$

Fig. 1. (a) Restriction map of the pUA510 insert and relative position of ORF1 and hisl. Solid boxes indicate the pBluescript SK polylinker. Only relevant sites are shown. (b) Ability of different fragments to complement $E$. coli and $R$. sphaeroides hisl mutants. Subclones were obtained either by the restriction enzymes indicated, or by exonuclease IIImediated deletions. Cloning vectors are shown in parentheses and the position of the lac promoter is indicated by an arrow. Only fragments cloned in PRK404 were tested in $R$. sphaeroides because PBSK is not stable in this organism (NT, not tested).

plating of several recombinant clones of each type on minimal medium, with and without histidine, showed that only the plasmid harbouring the $1.3 \mathrm{~kb}$ fragment (pUA510) complemented the mutation (Fig. 1a). Furthermore, cloning of this fragment in the opposite orientation in relation to the lac promoter of the vector also enabled the transformed UA4845 to grow in the absence of histidine. This result indicates that there is a $R$. sphaeroides promoter in the $1.3 \mathrm{~kb}$ fragment, which can be expressed in E. coli. 


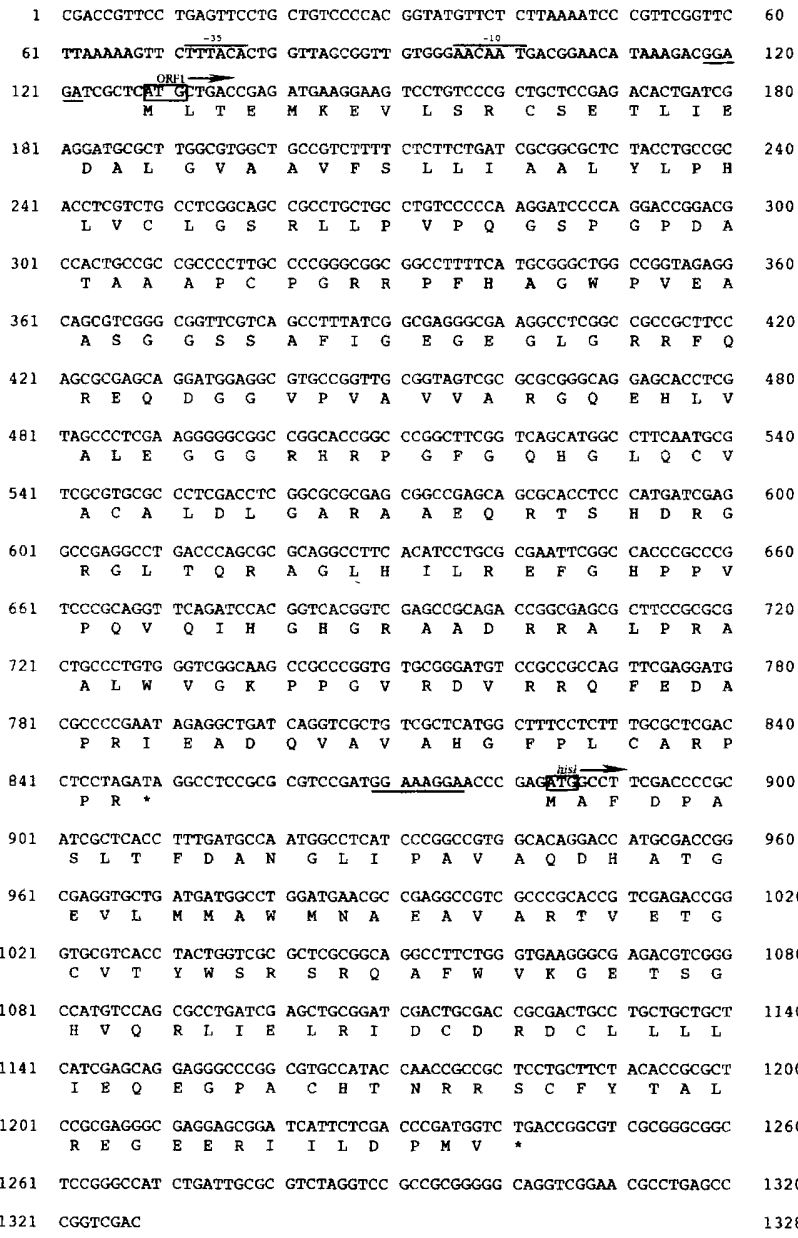

Fig. 2. Nucleotide sequence of the Sall-Sall fragment of pUA510. The deduced amino acid sequence is shown for ORF1 and hisl. Translational start codons are boxed, and arrows above them show the direction of transcription. Asterisks indicate translational stop codons. The putative RBSs preceding the predicted translational start codons are underlined. The -10 and -35 regions of the putative $\sigma^{70}$-like promoter located upstream of ORF1 are overlined.

In order to confirm that the cloned fragment belonged to the R. sphaeroides chromosome and that no reorganizations had taken place during the cloning process, a $0.7 \mathrm{~kb}$ EcoRI-HindIII fragment obtained from pUA510 was used as a probe to hybridize with total R. sphaeroides DNA digested with SalI. As expected, a hybridization band of $1.3 \mathrm{~kb}$ was detected (data not shown).

\section{Nucleotide sequence analysis of hisl}

The nucleotide sequence of the $1.3 \mathrm{~kb}$ fragment contained in pUA510 was determined (Fig. 2). Two ORFs were found; the overall $\mathrm{G}+\mathrm{C}$ content of the sequence is $67.3 \mathrm{~mol} \%$. This percentage, as well as the codon usage of the gene products, clearly biased towards $G$ and $C$ in the third position of the codon, is in agreement with the data from other known Rhodobacter genes.

ORF1 and its putative protein product show no significant homology with any other DNA or amino acid sequences

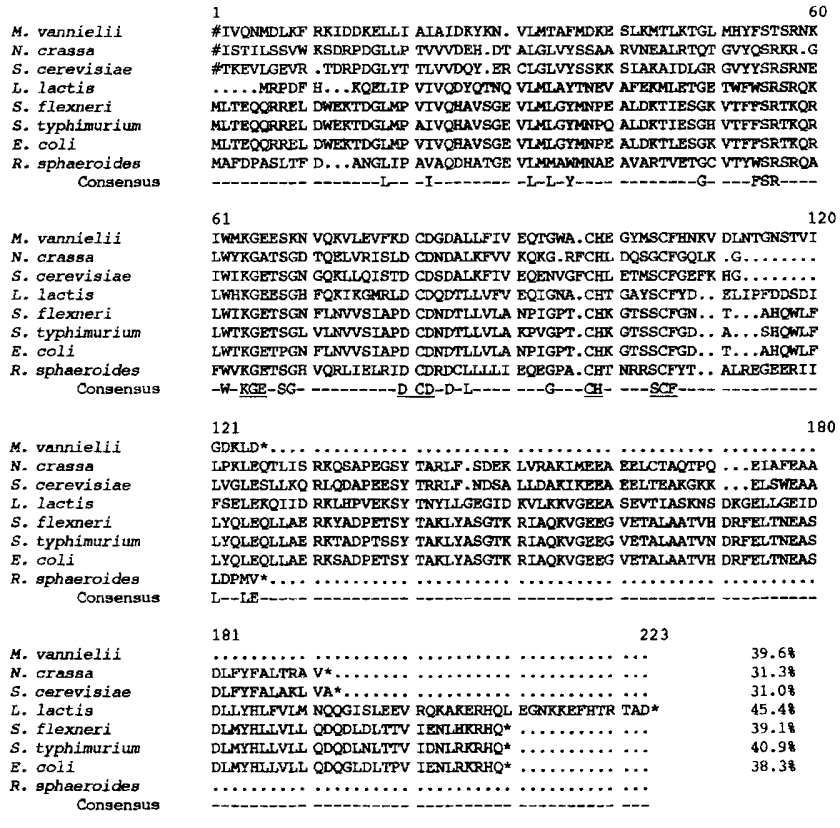

Fig. 3. Alignment of the deduced amino acid sequence of the $R$. sphaeroides hisl gene and those of the following microorganisms: Methanococcus vannielii (translated from EMBL data base, accession number X04021), Neurospora crassa (SwissProt accession number P07685), Saccharomyces cerevisiae (P00815), Lactococcus lactis (Q021130), Shigella flexneri (P37793), Salmonella typhimurium (P10367) and Escherichia coli (P06989). Asterisks show the carboxy-terminal extremity of each sequence; \# indicates the extremities of partial sequences; dots indicate inserted gaps to maximize the alignment. Highly conserved dipeptides and tripeptides are underlined. The consensus shows amino acids that are conserved in at least seven of the eight compared sequences. Percentages of identity between each amino acid sequence and that of $R$. sphaeroides are also indicated.

present in the databases. ORF1 is preceded by a putative ribosome-binding site (RBS) (Shine \& Dalgarno, 1975), located $7 \mathrm{bp}$ upstream of the ATG. The fact that the codon usage of ORF1 is very similar to those of other Rbodobacter genes suggests that it really is protein-coding sequence (Bibb et al., 1984).

Owing to its similarity to the bisI genes of other microorganisms, ORF2 was assigned to bisI. The R. sphaeroides hisI gene is found $33 \mathrm{bp}$ downstream of the ORF1 stop codon and there is a likely RBS, complementary to the $R$. sphaeroides 16S rRNA 3' end (Gibson et al., 1979), located $8 \mathrm{bp}$ upstream of the ATG. No putative promoter sequences or transcription stop signals were identified either upstream or downstream of the his I gene. The $R$. sphaeroides hisI gene is 360 bp long. Comparison with the E. coli and $S$. typhimurium bisIE $5^{\prime}$-terminal region (which encodes the cyclohydrolase activity) shows an overall identity of $62.7 \%$ and $59.6 \%$, respectively. The derived amino acid sequence is homologous to the $\mathrm{N}$-terminal domain of various HisIE proteins (Fig. 3), showing an overall $62.6 \%$ and $64.3 \%$ similarity to the HisIE peptides of $E$. coli and $S$. typhimurium, respectively. We therefore conclude that $R$. sphaeroides bisI encodes a unifunctional 
protein with a predicted molecular mass of $13.4 \mathrm{kDa}$, while the bifunctional E. coli and $S$. typhimurium proteins have a molecular mass of $22 \cdot 8 \mathrm{kDa}$.

The alignment of the sequences of the different gene products, as well as the percentages of identity with the predicted R. spbaeroides HisI, are shown in Fig. 3. When conservative substitutions are allowed, similarity is approximately $60 \%$. The similarities are not homogeneously distributed throughout the sequence. Amino acids $50-110$ of the $R$. sphaeroides protein show a higher degree of coincidence. As previously described (Beckler \& Reeve, 1986), this region is characterized by the conserved presence of three cysteines and three tripeptides (KGE, DCD, SCF), which are probably essential for the function of the protein.

The $1.3 \mathrm{~kb}$ fragment from $R$. sphaeroides was able to complement E. coli mutants regardless of its orientation in relation to the lac promoter of pBluescript SK. This could indicate that $R$. sphaeroides hisI was being transcribed in $E$. coli from its own promoter. Nevertheless, a subclone with a 250 bp deletion of the $5^{\prime}$ end of the pUA510 insert (Fig. 1b) was unable to complement the mutation although it carried an intact hisI gene, indicating that this region contains the promoter from which the transcription of the gene occurs. The analysis of the sequence demonstrated that the transcription of hisI in pUA510 might start at the preceding ORF1 promoter: a putative $\sigma^{70}$ promoter (Lang et al., 1995) is found $28 \mathrm{bp}$ upstream of the ORF1 translational start codon, with the presumptive -10 and -35 regions separated by 18 bp (Fig. 2). The homology with the $\sigma^{70}$ promoters of $E$. coli would allow recognition by the E. coli RNA polymerase.

An EcoRI-HindIII fragment of $0.7 \mathrm{~kb}$, which contained the whole hisI gene and just the $3^{\prime}$ end of ORF1, was cleaved from pUA510. Transformation of E. coli UA4845 showed that this fragment was able to complement the mutation only when it was cloned in the same orientation as the lac promoter from pBSK (Fig. 1b). This demonstrates that ORF1 is unnecessary for the expression of hisI in E. coli, so long as a promoter in the suitable orientation is provided.

\section{Construction of a $R$. sphaeroides his/ mutant}

To obtain a R. sphaeroides bisI mutant by marker exchange, the isolated hisI gene was disrupted by insertion of an $\Omega$ streptomycin/spectinomycin interposon (Fellay et al., $1987)$ into an internal ApaI site. After several subcloning steps, the mutated hisI gene was cloned in the suicide plasmid pSUP202 (Simon et al., 1983). The resulting construct, pUA534, was introduced into a wild-type strain of R. sphaeroides by triparental mating. Selection was carried out on $Z$ agar plates containing streptomycin and spectinomycin. Clones that had integrated the whole plasmid by single crossover were discarded by testing for tetracycline sensitivity. The resulting clones were plated on Pfennig plates with and without histidine in order to confirm the loss of the prototrophic phenotype.

The R. sphaeroides bisI mutant strain UA8123 was also analysed by Southern blotting. A $0.7 \mathrm{~kb}$ EcoRI-HindIII

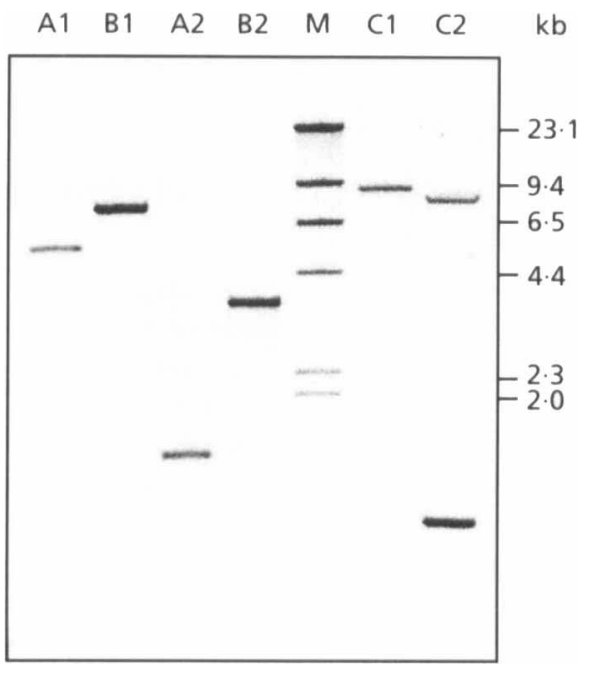

Fig. 4. Southern analysis of chromosomal DNA of both wildtype (lanes A) and UA8123 (lanes B) R. sphaeroides. A HindIII-ECoRI $0.7 \mathrm{~kb}$ probe was used to hybridize with genomic DNA digested with Smal (lanes. 1), Sall (lanes 2) and BamHI (lanes 3). Labelled $\lambda$ DNA digested with HindIII is also shown as a size standard (lane $M$ ).

fragment containing bisI was used as a probe against total DNA from both wild-type and UA8123 strains. The hybridization bands of the mutant, when digested with either Sall or SmaI, showed a decreased mobility in relation to the wild-type hybridization pattern, as was expected after the insertion of the $2 \mathrm{~kb} \Omega$ interposon (Fig. 4). On the other hand, when digested with BamHI, which cleaves the $\Omega$ interposon, the mutant strain showed two hybridization bands whose summed sizes equalled the size of the wild-type hybridization band.

An additional verification of the UA8123 hisI mutant consisted of testing for the recovery of the prototrophic phenotype when complemented in trans by the hisI gene. To do this, pUA509 was introduced into UA8123. All the resulting transconjugants were able to grow on minimal medium without histidine. These results demonstrate that the mutation caused by the insertion of the $\Omega$ interposon is not polar, at least concerning genes of histidine biosynthesis. Fragments BamHI-HindIII and BclI-HindIII (Fig. 1b) cloned in pRK404 were also able to complement UA8123. This demonstrates that the R. sphaeroides hisI is transcribed in this bacterium from an unidentified promoter which is located closer to the start codon. This promoter is not functional in $E$. coli, where the $R$. sphaeroides bisI gene is expressed from the previously described ORF1 promoter. Therefore, the main obstacle to the expression of the R. sphaeroides bisI gene in E. coli seems to reside in the recognition of its promoter. $R$. spbaeroides genes are seldom expressed in $E$. coli, because of differences at the transcriptional level, due to the different $\mathrm{G}+\mathrm{C}$ content $(68 \mathrm{~mol} \%$, in contrast to the $50 \mathrm{~mol} \%$ of $E$. coli).

The UA8123 mutant will be very useful for further complementation or transcriptional studies because it 
offers a mutated genetic background other than E. coli, where, as we have seen, some Rbodobacter promoters cannot be expressed.

\section{hisl and hisE genes are not physically linked in $R$. sphaeroides}

In E. coli, and many other micro-organisms, the HisI and HisE functions are encoded in a single gene which gives rise to a bifunctional protein. In S. cerevisiae (Bruni et al., 1986), the equivalent to bisI (bis $4 A$ ) is fused to bis $4 B$ (equivalent to bisE) as well as to $h i s 4 C$ (equivalent to $h i s D$, which in turn catalyses two steps of the pathway). In contrast, the bisI gene of the archaeobacterium Methanococcus vannielii encodes a unifunctional protein and unifunctional bisE genes have been found in Azospirillum brasilense and Streptomyces coelicolor.

The analysis of the R. spbaeroides bisI sequence and the absence of polarity of the bis $I:: \Omega \mathrm{Sp} / \mathrm{Sm}$ mutant suggested that hisI and hisE were not physically linked in this microorganism. To confirm this hypothesis, plasmid pUA509 was introduced into S. typhimurium E311. This strain lacks the HisE function, but not that of HisI. The presence of pUA509 in S. typhimurium E311 cells did not abolish their $\mathrm{His}^{-}$phenotype. Moreover, we obtained plasmid pUA556, which contains an $8.8 \mathrm{~kb}$ insert, by complementation of UA1701 (bisE) with the R. sphaeroides genomic library. Different bisI mutant strains of E. coli and S. typhimurium carrying pUA556 were unable to grow in the absence of histidine, suggesting that the bisI and bis $E$ functions are encoded in independent genes in $R$. sphaeroides, and that these genes lie relatively far apart on the chromosome.

\section{Chromosomal localization of the $R$. sphaeroides hisl gene}

To locate the hisI gene on the physical map of the $R$. sphaeroides chromosome, total DNA of $R$. sphaeroides was extracted and digested with the low-cutting-frequency enzymes $A s e \mathrm{I}$ and DraI. The digestion products were separated by PFGE, transferred to a nylon membrane and hybridized with a $0.7 \mathrm{~kb}$ probe containing hisI. The AseI digestion showed a single hybridization band of $1100 \mathrm{~kb}$, which corresponds to fragment A described by Suwanto \& Kaplan (1989a). DraI digestions showed a single hybridization band of $660 \mathrm{~kb}$, designated as band $\mathrm{C}$ by Suwanto \& Kaplan (1989b).

To determine the precise location of the gene in these bands, we took advantage of the fact that the $\Omega$ interposon contains AseI and DraI restriction sites. Therefore, restriction of the DNA from the mutant strain with these enzymes will cause the cleavage of a specific band into two new fragments, which can be directly detected after electrophoresis. Total DNA from both R. sphaeroides UA8123 and 2.4.1 was digested with AseI and DraI. After separation by PFGE, the lane corresponding to the UA8123 AseI-digested DNA showed two bands of $420 \pm 20$ and $680 \pm 20 \mathrm{~kb}$ in size, which did not appear in the lane corresponding to the wild-type strain, while the

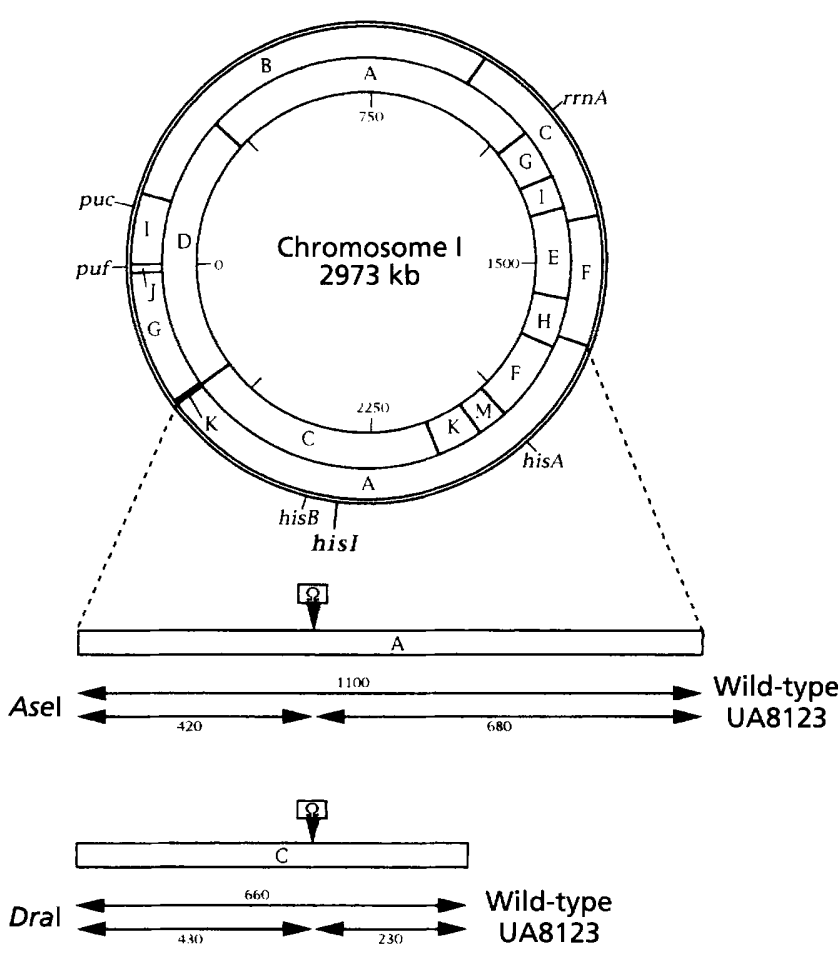

Fig. 5. Physical location of the $R$. sphaeroides hisl gene (in bold) in chromosome $\mathrm{I}$, deduced from the sizes of the hybridization bands obtained after pulsed-field gel electrophoresis of chromosomal DNA from both wild-type and UA8123 $R$. sphaeroides, digested with Asel and Dral. Cleavage map for Asel (outer circle) and Dral (inner circle), map co-ordinates and some previously reported genes are indicated as a reference (Mackenzie et al., 1995).

$1100 \mathrm{~kb}$ band had disappeared. On the other hand, the UA8123 DraI-digested DNA produced two bands, of $230 \pm 10$ and $430 \pm 10 \mathrm{~kb}$ in size, instead of the $660 \mathrm{~kb}$ band of the wild-type. These results were confirmed by hybridization using the EcoRI-HindIII bisI probe.

Taking these data into account, the R. sphaeroides bisI gene could only be located at co-ordinate $2275 \pm 20 \mathrm{~kb}$ of chromosome I, that is, about $420 \mathrm{~kb}$ from the $A s e \mathrm{I} \mathrm{A-K}$ and DraI C-D junctions (Fig. 5), according to the R. sphaeroides map co-ordinates described by Mackenzie et al. (1995).

Finally, to confirm that hisI and bisE are not physically linked, a DNA fragment from pUA556 was used as a probe to hybridize with $A s e \mathrm{I}$ and $D r a \mathrm{I}$ digests of $\mathrm{R}$. sphaeroides 2.4.1 genomic DNA. The probe hybridized with the AseI A (1100 kb) and the DraI M (55 kb) bands (Mackenzie et al., 1995). This confirms that there are about $300 \mathrm{~kb}$ between the hisI and hisE genes of $R$. sphaeroides, and also that the histidine biosynthesis genes in this bacterium are not encoded in a single transcriptional unit like that of Enterobacteriaceae. In agreement with this, the $R$. sphaeroides bis $A$ and bis $B$ genes have been determined to be located approximately at map co-ordinates 1900 and 2350 of chromosome I, respectively (Mackenzie et al., 1995). 


\section{ACKNOWLEDGEMENTS}

We wish to thank Dr N. Gaju for her advice and help with PFGE experiments, as well as Dr C. B. Bruni for the generous gift of several bacterial strains. This work was funded by grant PB94-0687 of the Dirección General de Investigación Cientifica y Técnica of Spain (DGICYT) and by grant GRQ932049 from the Comissionat per Universitats i Recerca de la Generalitat de Catalunya. E.O. was the recipient of a predoctoral fellowship from the Direcció General d'Universitats de la Generalitat de Catalunya. We gratefully acknowledge the help of the Direcció General d'Universitats de la Generalitat de Catalunya for different grants for the purchase of equipment.

\section{REFERENCES}

Ausubel, F. M., Brent, R., Kingston, R. E., Moore, D. D., Seidman, J. G., Smith, J. A. \& Struhl, K. (1989). Current Protocols in Molecular Biology. New York: Greene Publishing Associates \& WileyInterscience.

Bazzicalupo, M., Fani, R., Gallori, E., Turbantini, L. \& Polsinelli, M. (1987). Cloning of the histidine, pyrimidine, and cysteine genes of Azospirillum brasilense. Expression of pyrimidine and three clustered histidine genes in Escherichia coli. Mol Gen Genet 206, 76-80.

Becker-Rudzik, M., Young, D. A. \& Marrs, B. L. (1992). Sequence of the indolglycerol phosphate synthase $(\operatorname{tr} p C)$ gene from Rhodobacter capsulatus. J Bacteriol 174, 5482-5484.

Beckler, G. S. \& Reeve, J. N. (1986). Conservation of the primary structure in the bisI gene of the archaebacterium Methanococcus vannielii, the eubacterium E. coli and the eucaryote Sacharomyces cerevisiae. Mol Gen Genet 204, 133-140.

Bibb, M. J., Findlay, P. R. \& Johnson, M. W. (1984). The relationship between base composition and codon usage in bacterial genes and its use for the simple and reliable identification of protein-coding sequence. Gene 30, 157-166.

Bruni, C. B., Carlomagno, M. S., Formisano, S. \& Paolella, G. (1986). Primary and secondary structural homologies between the HIS4 gene product of Saccharomyces cerevisiae and the bisIE and bisD gene products of E. coli and S. typhimurium. Mol Gen Genet 203, 389-396.

Carlomagno, M. S., Chiarotti, L., Alifano, P., Nappo, A. G. \& Bruni, C. B. (1988). Structure and function of the Salmonella typhimurium and Escherichia coli K-12 histidine operons. J Mol Biol 203, 585-606.

Clark, D. J. \& Maaløe, O. (1967). DNA replication and the division cycle of E. coli. J Mol Biol 23, 99-112.

Delorme, C., Ehrlich, S. D. \& Renault, P. (1992). Histidine biosynthesis genes in Lactococcus lactis subsp. lactis. J Bacteriol 174, 6571-6579.

Ditta, G., Schmidthauser, T., Yakobson, E., Lu, P., Liang, X. V., Finlay, D. R., Guiney, D. \& Helinski, D. R. (1985). Plasmids related to the broad host range vector pRK290, useful for gene cloning and for monitoring gene expression. Plasmid 13, 149-153.

Donhaue, T. F., Parabaugh, P. J. \& Fink, G. R. (1982). The nucleotide sequence of the HIS4 region of yeast. Gene 18, 47-59.

Dower, J. W., Miller, F. J. \& Ragsdale, W. C. (1988). High efficiency transformation of E. coli by high voltage electroporation. Nucleic Acids Res 16, 6127-6145.

Fani, R., Alifano, P., Allotta, G., Bazzicalupo, M., Carlomagno, M. S., Gallori, E., Rivellini, F. \& Polsinelli, M. (1993). The histidine operon of Azospirillum brasilense: organization, nucleotide sequence and functional analysis. Res Microbiol 144, 187-200.

Fellay, R., Frey, J. \& Krisch, H. (1987). Interposon mutagenesis of soil and water bacteria : a family of DNA fragments designed for in vitro insertional mutagenesis of Gram-negative bacteria. Gene 52, 147-154.

Gibson, J., Stackenbrandt, E., Zablen, L. B., Gupta, R. \& Woese, C. R. (1979). A phylogenetic analysis of the purple photosynthetic bacteria. Curr Microbiol 3, 59-64.

Goldschmidt, E. P., Cater, M. S., Matney, T. S., Butler, M. A. \& Greeve, A. (1970). Genetic analysis of the histidine operon in E. coli K12. Genetics 66, 219-229.

Hanahan, D. (1983). Studies on transformation of E. coli with plasmids. J Mol Biol 166, 557-580.

Hartman, P. E., Hartman, Z., Stahl, R. C. \& Ames, B. (1971). Classification and mapping of spontaneous and induced mutations in the histidine operon of Salmonella. Adv Genet 16, 1-34.

Henner, D. J., Band, L., Flaggs, G. \& Chen, E. (1986). The organization and nucleotide sequence of the Bacillus subtilis his $H$, tyr $A$ end aroE genes. Gene 49, 147-152.

Lang, H. P., Cogdell, R. J., Takaichi, S. \& Hunter, C. N. (1995). Complete DNA sequence, specific Tn 5 insertion map, and gene assignment of the carotenoid biosynthesis pathway of Rhodobacter sphaeroides. J Bacteriol 177, 2064-2073.

Legerton, T. L. \& Yanofsky, C. (1986). Cloning and characterization of the multifunctional bis 3 gene of Neurospora crassa. Gene 39, 129-140.

Limauro, D., Avitabile, A., Cappeliano, C., Puglia, A. M. \& Bruni, C. B. (1990). Cloning and characterization of the histidine biosynthetic gene cluster of Streptomyces coelicolor A3(2). Gene 90, 31-41.

Mackenzie, C., Chidambaram, M., Sodergren, E. J., Kaplan, S. \& Weinstock, G. M. (1995). DNA repair mutants of R. sphaeroides. J Bacteriol 177, 3027-3035.

Martin, R. G., Berberich, M. A., Ames, B. N., Davis, W. W. Goldberger, R. F. \& Yourno, J. D. (1971). Enzymes and intermediates of histidine biosynthesis in Salmonella typhimurium. Methods Enzymol 17B, 3-44.

Miller, J. H. (1992). A Short Caurse in Bacterial Genetics, Handbook. New York: Cold Spring Harbor Laboratory.

O’Byrne, C. P., Ní Bhriain, N. \& Dorman, C. J. (1992). The DNA supercoiling-sensitive expression of the Salmonella typbimurium bis operon requires the his attenuator and is modulated by anaerobiosis and by osmolarity. Mol Microbiol 6, 2467-2476.

Pemberton, J. M. \& Bowen, A. R. St G. (1981). High frequency chromosome transfer in Rhodopseudomonas sphaeroides promoted by broad-host range plasmid RP1 carrying mercury transposon $\operatorname{Tn} 501$. J Bacteriol 147, 110-117

Pfennig, N. \& Trupper, H. G. (1983). Taxonomy of phototrophic green and purple bacteria: a review. Ann Microbiol 134, 9-20.

Sambrook, J., Fritsch, E. F. \& Maniatis, T. (1989). Molecular Cloning: a Laboratory Manual, 2nd edn. New York: Cold Spring Harbor Laboratory.

Sanger, F., Nicklen, S. \& Coulson, A. R. (1977). DNA sequencing with chain terminating inhibitors. Proc Natl Acad Sci USA 74, 5463-5467.

Shine, J. \& Dalgarno, L. (1975). Determinant of cistron specificity in bacterial ribosomes. Nature 254, 34-38.

Simon, R., Priefer, U. \& Puhler, A. (1983). A broad host range mobilization system for in vivo genetic engineering: transposon mutagenesis in gram negative bacteria. Biotechnology 11, 784-791. 
Smith, C. L. \& Cantor, C. R. (1987). Purification, specific fragmentation and separation of large DNA molecules. Methods Enzymol $155,449-467$.

Suwanto, A. \& Kaplan, S. (1989a). Physical and genetic mapping of the R. sphaeroides 2.4 .1 genome: genome size, fragment identification and gene localization. J Bacteriol 171, 5840-5849.

Suwanto, A. \& Kaplan, S. (1989b). Physical and genetic mapping of the $R$. sphaeroides 2.4 .1 genome: presence of two unique circular chromosomes. J Bacteriol 171, 5850-5859.

Winkler, M. E. (1987). Biosynthesis of histidine. In Escherichia coli and Salmonella typhimurium: Cellular and Molecular Biology, vol. 1, pp. 395-411. Edited by F. C. Neidhardt, J. L. Ingraham, K. Brooks Low, B. Magasanik, M. Schaechter \& H. E. Umbarger. Washington, DC: American Society for Microbiology.

Zinchenko, V., Churin, Y., Shestopalov, V. \& Shestakov, S. (1994). Nucleotide sequence and characterization of the Rbodobacter sphaeroides gln B and $g \ln A$ genes. Microbiology 140, 2143-2151.

Received 2 February 1996; revised 1 April 1996; accepted 17 April 1996. 